\title{
Uji Kinerja dan Analisis Ekonomi Mesin Pemecah Cangkang Kemiri Sunan MPC KS-0218 Jenis Ayakan Getar
}

\author{
Performance Test and Economic Analysis of Kemiri Sunan Shell Breaker MPC KS-0218 Vibrating Sifter Type \\ Wahyu K. Sugandi ${ }^{\star *}$, M. Ade Moetangad Kramadibrata ${ }^{1}$, Asep Yusuf ${ }^{1}$, Eka Aria Putra²

\begin{abstract}
1Departemen Teknik Pertanian dan Biosistem, Fakultas Teknologi Industri Pertanian, Universitas Padjadjaran
*Alumni Program Studi Teknik Pertanian, Fakultas Teknologi Industri Pertanian, Universitas Padjadjaran Jalan Raya Bandung-Sumedang Km 21, Jatinangor 40600

*E-mail: sugandiwahyu@gmail.com
\end{abstract}

Diterima: 20 September 2019; Disetujui: 21 Desember 2020

\begin{abstract}
ABSTRAK
Minyak dari hasil pengolahan inti kemiri sunan dapat digunakan sebagai bahan baku pembuatan biodiesel setelah melalui berbagai tahap proses pasca panen, oleh karena itu kemiri sunan dapat menjadi alternatif energi yang dapat diperbaharui (renewable). Mesin pemecah kemiri sunan (MPC KS-0218) jenis ayakan getar belum memiliki spesifikasi teknis dan kelayakan ekonomi, sehingga mesin belum dapat didistribusikan dan diperjualbelikan secara layak ke masyarakat pengguna/pelaku usaha kemiri sunan. Penelitian ini bertujuan untuk melakukan uji kinerja dan analisis ekonomi mesin pemecah cangkang kemiri sunan. Metode penelitian yang digunakan adalah analisis deskriptif, yaitu melakukan pengukuran dan pengamatan terhadap kinerja mesin pemecah cangkang kemiri sunan beserta analisis ekonominya. Data yang diperoleh kemudian dianalisis untuk menentukan kelayakan dalam segi fungsional dan ekonomi dari mesin tersebut. Hasil uji kinerja menunjukkan mesin pemecah cangkang kemiri sunan belum layak secara teknis karena 4 dari 9 parameter tidak memenuhi kriteria, yaitu nilai kapasitas aktual $49 \mathrm{~kg} / \mathrm{jam}$, efisiensi mesin $42 \%$, kebutuhan daya sebesar 0,22 kW, energi spesifik $17,08 \mathrm{~kJ} / \mathrm{kg}$, rendemen 39,5\%, tingkat kebisingan dibawah ambang batas sebesar $87,72 \mathrm{~dB}$, tingkat getaran diatas ambang batas sebesar $13,41 \mathrm{~m} / \mathrm{s}^{2}$ dan indeks performansi 0,72 . Hasil analisis ekonomi mesin MPC KS-0218 memiliki nilai yang belum layak secara ekonomis karena 1 dari 4 parameter, yaitu nilai NPV Rp. 77.043.681,20 (NPV >0), nilai IRR > suku bunga MARR $(10 \%)$ dengan nilai IRR $51,98 \%$ dengan periode pengembalian modal pada tahun ke 2 , lalu b/c ratio $\geq$ 1 dengan nilai 1,08 (b/c ratio yang direkomendasikan $1,1-1,4)$.
\end{abstract}

Kata kunci: pemecah cangkang kemiri sunan; uji kinerja, analisis ekonomi, MPC KS-0218

\section{ABSTRACT}

Oil from the processing of kemiri sunan core can be used as raw material for making biodiesel after going through various stages of the post-harvest process; therefore kemiri sunan can be an alternative renewable energy. Kemiri sunan breaking machine (MPC KS-0218) is type of vibrating sieve does not yet have technical specifications and economic feasibility, so that the machine cannot be distributed and traded properly to the community of users or kemiri sunan businessmen. This study aims to the performance tests and economic analysis of kemiri sunan shell breaking machines. The research method used is descriptive analysis, which is measuring and observing the performance of the kemiri sunan shell breaking machine and its economic analysis. The data obtained is then analyzed to determine the feasibility in terms of the functional and economic aspects of the machine. The results of the performance test have shown that the kemiri sunan shell breaker machine is not technically feasible because 4 out of 9 parameters do not fulfilling the criteria, namely the actual capacity value of $49 \mathrm{~kg} /$ hour, engine efficiency $42 \%$, power requirements of $0.22 \mathrm{~kW}$, specific energy $17.08 \mathrm{~kJ} / \mathrm{kg}$, yield of $39.5 \%$, noise level below the threshold of $87.72 \mathrm{~dB}$, vibration level above the threshold of $13.41 \mathrm{~m} / \mathrm{s}^{2}$ and performance index of 0.72 . The results of economic analysis of the KS MPC-0218 machine has a value that is not economically feasible for one of the four parameters, the NPV value of Rp. 77,043,681.20 (NPV >0), IRR value > MARR interest rate (10\%) with an IRR value of $51.98 \%$ with a payback period in year 2 , then b/c ratio $\geq 1$ with a value of 1.08 (recommended b/c ratio $1.1-1.4$ ).

Keywords: kemiri sunan breaker machine; performance test; economic analysis; MPC KS-0218

\section{PENDAHULUAN}

Motor bakar adalah suatu alat yang berfungsi untuk mengonversikan energi termal dari proses pembakaran bahan bakar menjadi energi mekanis atau mengubah tenaga kimia bahan bakar menjadi tenaga mekanis. Energi yang diperoleh dari hasil pembakaran tersebut dilaksanakan didalam mesin dan luar mesin kalor (Kiyaku dan Murdhana, 1998).

Kemiri sunan (Reutealis trisperma (Blanco) Airy Shaw) adalah salah satu tanaman potensial penghasil minyak nabati (Heyne, 1987). Inti yang terdapat di dalam bijinya mengandung minyak dengan rendemen sekitar $50 \%$ (Herman dan Pranowo, 2009). Minyak yang didapatkan dari inti kemiri sunan tersebut dengan melalui berbagai tahapan proses pasca panen dapat digunakan untuk alternatif energi yang dapat diperbaharui (renewable) berupa biodiesel (Vossen dan Umali, 2002). Berdasarkan data dari laman resmi Balai Pengkajian Teknologi Pertanian (BPTP) Jawa Barat pada tahun 2017 mengenai kemiri sunan, pembuatan biodiesel dari kemiri sunan sendiri masih dicanangkan. Oleh karena itu pengolahan pasca panen pada kemiri 
sunan perlu dilakukan. Proses pengolahan kemiri sunan menjadi biodiesel pada tahap pertama adalah dengan memecahkan cangkangnya.

Motor bakar menggunakan bahan bakar berupa minyak fosil yang semakin hari semakin terbatas (non-renewable), oleh karena itu banyaknya penggunaaan bahan bakar fosil harus mulai dikurangi. Pembuatan bahan bakar alternatif dari bahan yang dapat diperbaharui (renewable) dapat menjadi pilihan untuk mengurangi penggunaan bahan bakar fosil tersebut (Saravacos, G. \& Kostaropaulos, A., 2002).

Pemecahan cangkang kemiri sunan dapat dilakukan dengan proses manual yaitu dengan cara dipukul akan tetapi membutuhkan tenaga dan waktu yang banyak, oleh karena dibutuhkan bantuan alat untuk mempercepat proses pemecahan cangkang tersebut. Luaran dari pemecahan cangkang kemiri sunan adalah inti kemiri sunan dan cangkangnya yang masih bercampur, dan membutuhkan waktu yang lama untuk memisahkannnya dengan cara manual. Oleh karena itu, diperlukan mesin pemecah cangkang kemiri sunan agar proses pemecahan dan pemisahannya dapat dilakukan dengan cepat.

Laboratorium Pasca Panen dan Teknologi Proses Fakultas Teknologi Industri Pertanian (FTIP) Universitas Padjadjaran (UNPAD) pada tahun 2017 menggunakan telah menggunakan mesin pemecah kemiri sunan MPC KS0117 jenis ayakan rotasi, akan tetapi hasilnya kurang memuaskan. Tahun 2018 mesin pemecah cangkang kemiri sunan dimodifikasi menjadi jenis ayakan getar dengan nama mesin MPC KS-0218. Modifikasi mesin MPC KS0218 menggunakan jenis ayakan getar untuk memisahkan cangkang dan biji sebelum keluar melalui saluran outputnya yang bertujuan untuk meningkatkan performa mesin pemecah cangkang kemiri sunan tersebut.

Mesin pemecah kemiri sunan MPC KS-0218 belum memiliki spesifikasi teknis dan kelayakan ekonomi mesin, sehingga mesin belum dapat didistribusikan dan diperjualbelikan secara layak ke masyarakat pengguna/pelaku usaha kemiri sunan. Biaya pembelian serta biaya operasional yang dikeluarkan oleh pihak terkait juga besar, khususnya untuk biaya pembuatan mesinnya (Lab. Pasca Panen dan Tek. Proses FTIP, 2018). Biaya yang telah dihitung sampai sekarang masih pada tahap investasi mesin, sedangkan biaya pengoperasian mesin belum dihitung.

Data penjualan mesin dari laman toko daring di Indonesia mesin pemecah kemiri sayur banyak dijual secara massal, akan tetapi khusus untuk mesin pemecah kemiri sunan belum dijual di pasaran secara massal. Oleh karena itu belum banyak praktisi yang berkecimpung pada bidang biodiesel kemiri sunan tersebut.

Mesin pemecah kemiri sunan MPC KS-0218 jenis ayakan getar merupakan salah satu terobosan baru dalam proses pengolahan kemiri sunan, akan tetapi belum memiliki spesifikasi teknis dan ekonomisnya. Berdasarkan data yang telah dipaparkan bahwa perlu dilakukan pengujian kinerja mesin serta analisis kelayakan ekonomi mesin pemecah kemiri sunan MPC KS-0218 jenis sortasi getar.

\section{METODOLOGI PENELITIAN}

Metode penelitian yang diterapkan adalah metode analisis deskriptif, yaitu dengan melakukan pengukuran, pengamatan dan perhitungan terhadap komponenkomponen struktural serta kinerja fungsional mesin (Kuncoro, 2003). Data yang didapatkan kemudian dianalisis, sehingga memperoleh gambaran berupa hasil spesifikasi kemampuan kinerja mesin pemecah kemiri sunan jenis ayakan getar. Data yang didapatkan dari hasil penelitian ini akan dapat memberikan keuntungan mengenai data spesifikasi mesin pemecah cangkang kemiri sunan jenis ayakan getar serta memberikan informasi menyeluruh bagi pengguna mesin. Analisis ekonomi digunakan untuk mengetahui nilai ekonomis dan kelayakan ekonomi pada pendirian suatu sistem (Kastaman, R. 200)4.

Alat-alat yang digunakan pada penelitian ini antara lain meteran, gelas ukur, jangka sorong, stopwatch, tachometer, soundlevelmeter, timbangan digital, vibration meter dan clampmeter. Bahan baku yang digunakan pada penelitian ini adalah biji kemiri sunan. Uji kinerja mesin pemecah kemiri sunan (Gambar 1) dilakukan sebanyak 5 kali dengan bahan yang digunakan setiap ulangannya sebesar $5 \mathrm{~kg}$ (RNAM, 1995). Total biji kemiri yang digunakan untuk uji kinerja mesin pemecah cangkang kemiri sunan jenis ayakan getar yaitu lebih besar dari $20 \mathrm{~kg}$.

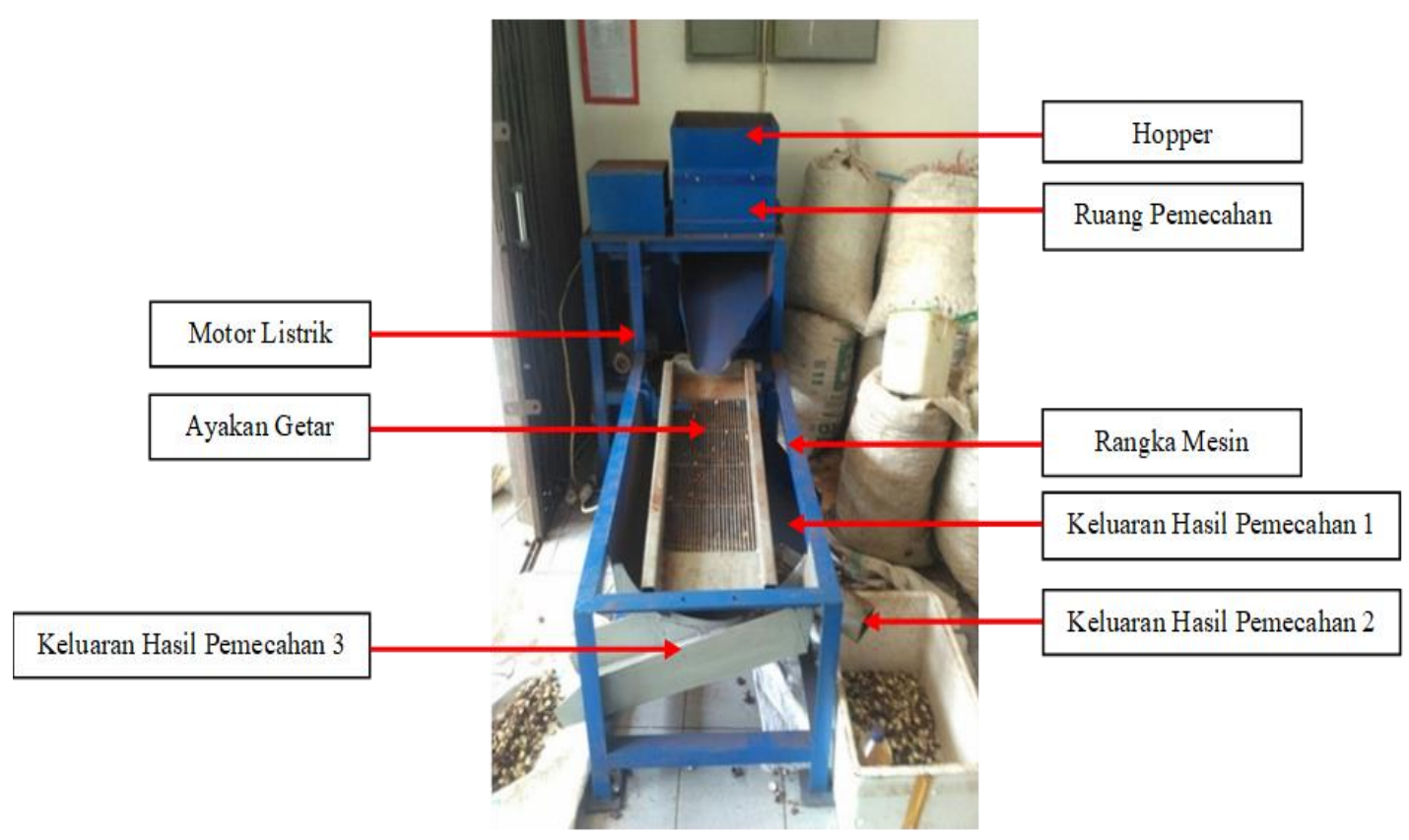

Gambar 1. Mesin pemecah kemiri sunan 


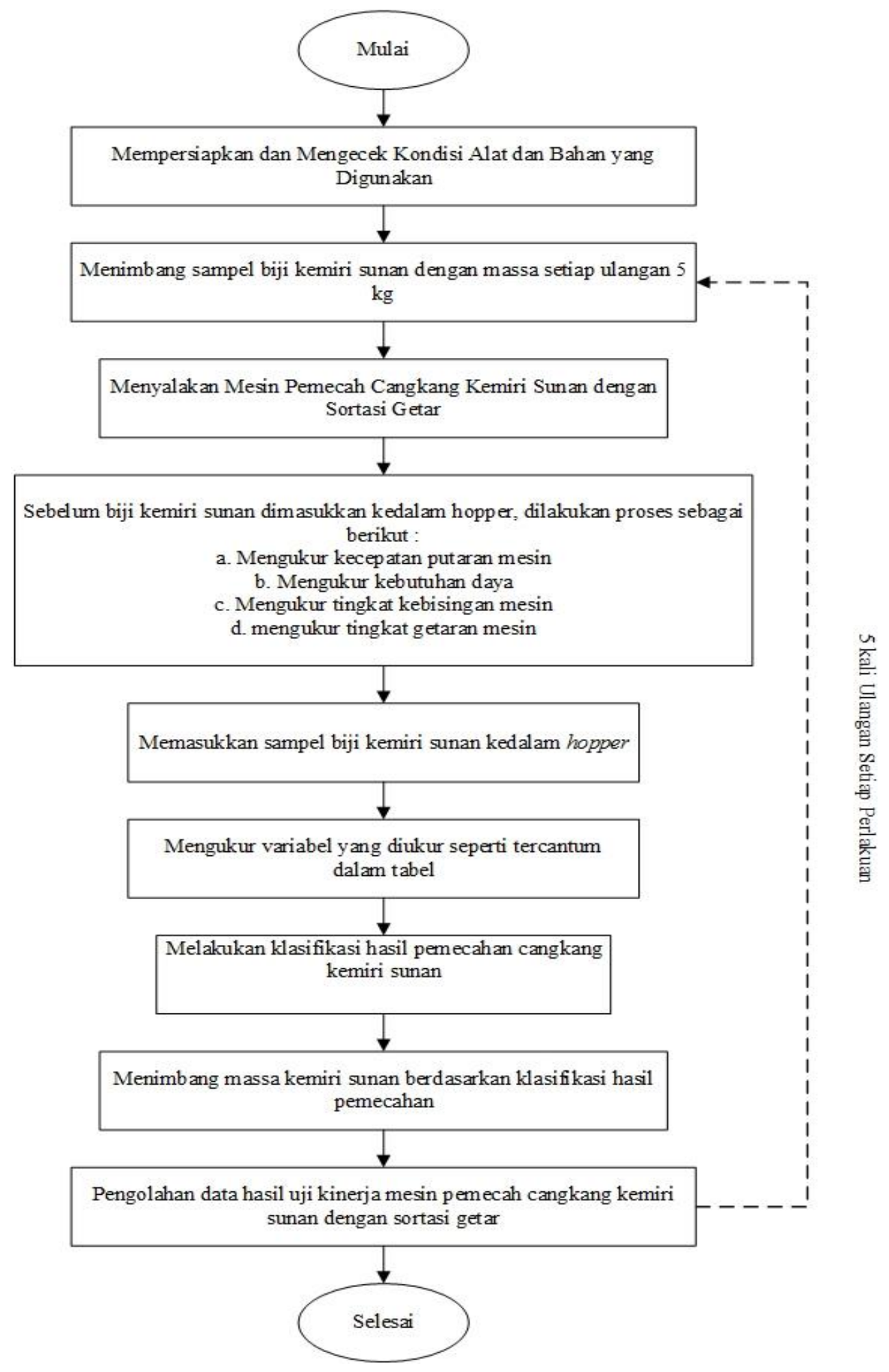

Gambar 2. Diagram Alir Uji Kinerja Mesin MPC KS-0218 


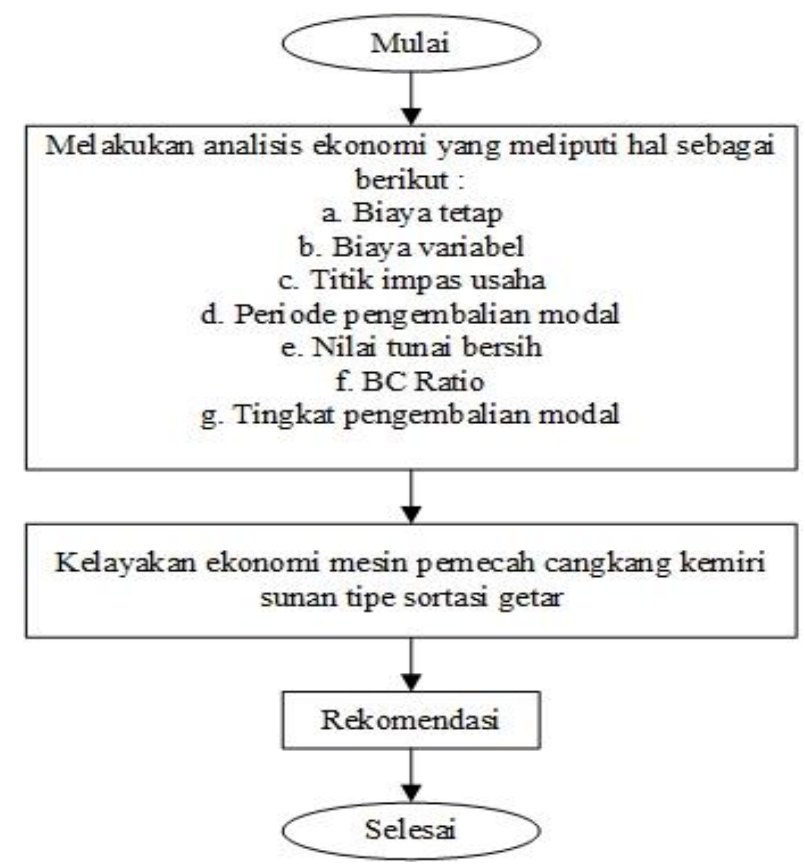

Gambar 3. Diagram Alir Analisis Ekonomi Mesin MPC KS-0218

Standar Nasional Indonesia (SNI) No. SNI 4511-2011 menjadi acuan untuk melakukan tahapan uji kinerja mesin (Gambar 2), parameter tambahan pada perlakuan uji kinerja mesin pemecah kemiri sunan adalah ayakan getar.

Adapun tahapan analisis kelayakan ekonomi dari mesin pemecah kemiri sunan jenis ayakan getar seperti yang disajikan pada Gambar 3.

\section{HASIL DAN PEMBAHASAN}

\section{Uji Kinerja}

Pengujian kinerja mesin pemecah kemiri sunan bertujuan untuk mengevaluasi hasil kerja mesin secara kuantitas dan kualitas. Uji kinerja mesin meliputi beberapa parameter diantaranya adalah (1) kapasitas teoritis, (2) kapasitas aktual, (3) efisiensi, (4) kebutuhan daya, (5) energi spesifik, (6) putaran poros, (7) rendemen, (8) tingkat kebisingan, (9) tingkat getaran, (10) tingkat kebersihan, dan (11) indeks performansi mesin (Badan Standarisasi Nasional, 2013).

\section{Kapasitas Teoritis Mesin}

Kapasitas teoritis mesin pemecah cangkang kemiri sunan MPC KS-0218 adalah besaran massa bahan $(\mathrm{kg})$ yang dapat diproses oleh mesin tersebut pada satuan waktu yang dapat dihitung secara teoritis. Pendekatan untuk mengetahui nilai kapasitas teoritis dapat dihitung dengan mengukur panjang baris celah rol pemecah, lalu biji kemiri sunan diasumsikan berada tepat pada keseluruhan rol pemecah. Pendekatan untuk mengetahui nilai kapasitas teoritis dilakukan terhadap bagian rol pemecah. Nilai kapasitas teoritis hasil perhitungan ialah sebesar 118 $\mathrm{kg} / \mathrm{jam}$.

Nilai kapasitas teoritis berbanding lurus dengan nilai kerapatan kamba suatu bahan, apabila semakin kecil nilai kerapatan kamba suatu bahan maka semakin kecil pula kapasitas teoritis pemecahan bahan tersebut. Dari nilai kerapatan kamba yang diketahui bahwa biji kemiri sunan lebih kecil daripada biji kemiri sayur, maka kapasitas teoritis pemecahannya lebih kecil daripada kapasitas teoritis pemecahan kemiri sayur. Ditinjau dari nilai kapasitas teoritis yang diperoleh lalu dibandingkan dengan kriteria perancangannya maka mesin telah memenuhi kriteria perancangan.

\section{Kapasitas Aktual Mesin}

Kapasitas aktual mesin pemecah kemiri sunan MPC KS-0218 adalah kemampuan mesin untuk memecahkan cangkang kemiri sunan untuk memperoleh inti kemiri sunan dalam periode waktu tertentu. Pengukuran kapasitas aktual mesin ini adalah menggunakan sampel biji kemiri sunan sebanyak $5 \mathrm{~kg}$ untuk setiap ulangan pengujian dan dilakukan sebanyak 5 kali. Kapasitas aktual memiliki nilai sebesar 49 kg/jam (Gambar 4).

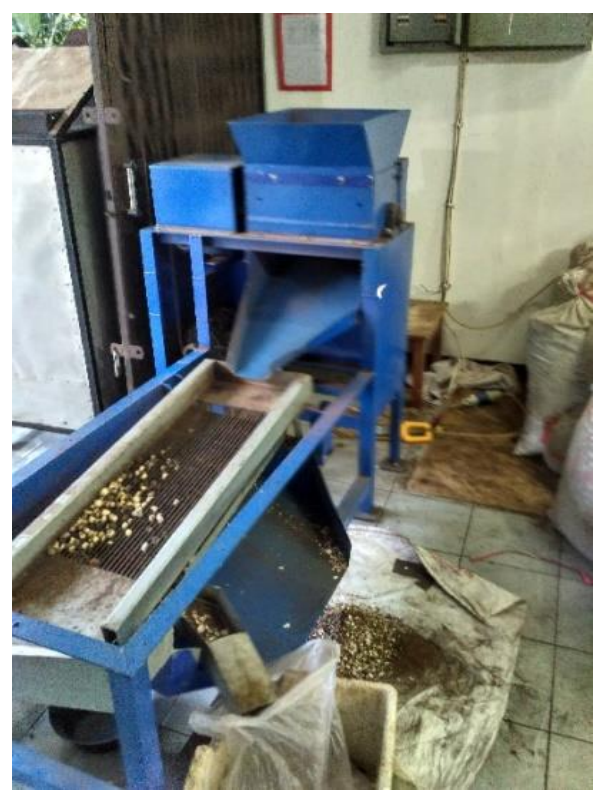

Gambar 4. Kapasitas aktual mesin pemecah kemiri sunan

Nilai kapasitas aktual yang rendah tersebut terjadi karena pengoprasian mesin sangat bergantung pada 
operator, operator harus mengatur banyaknya bahan masuk menuju ruang pemecahan karena pada bagian alas hopper hanya memiliki lubang yang sempit dengan ukuran Panjang $33,5 \mathrm{~cm}$ dan lebar $4 \mathrm{~cm}$. Untuk meningkatkan kapasitas aktual perlu dilakukan modifikasi pada bagian alas hopper dengan memperlebar lubang pada alas hopper (batas menuju ruang pemecahan), selanjutnya dapat dibuat penutup lubang hopper (menuju ruang pemecahan).

\section{Efisiensi Mesin}

Efisiensi mesin pemecah kemiri sunan MPC KS-0218 didapatkan dengan menghitung perbandingan antara nilai kapasitas aktual mesin dengan nilai kapasitas teoritisnya. Efisiensi mesin memiliki nilai sebesar $42 \%$. Nilai efisiensi akan semakin besar apabila kapasitas aktual mesin juga lebih besar. Nilai efisiensi tersebut tidak memenuhi kriteria karena hanya didapatkan nilai rata-rata sebesar $42 \%$ yang sangat jauh dari nilai standar untuk efisiensi mesin sebesar 80-90\% (Saravacos \& Kostaropaulos, 2002). Nilai tersebut disebabkan rendahnya kapasitas aktual dibandingkan dengan kapasitas teoritisnya. Kapasitas aktual mesin yang rendah disebabkan karena proses pemecahan masih bergantung pada operator yang mengatur masuknya bahan menuju ruang pemecahan dan lubang pada hopper yang sempit menyebabkan operator harus memasukkan bahan secara perlahan sedikit demi sedikit. Sehingga perlu adanya mofifikasi hoper seperti pada (Gambar 5).

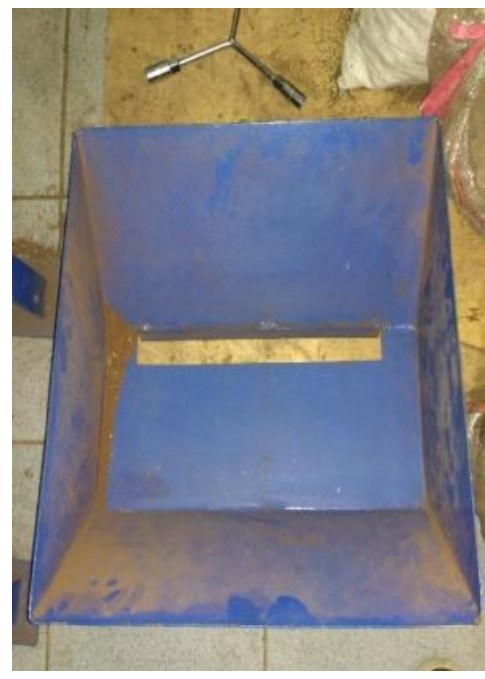

Gambar 5. Hoper

\section{Kebutuhan Daya Aktual Mesin}

Kebutuhan daya mesin pemecah cangkang kemiri sunan MPC KS-0218 dapat diukur menggunakan alat clampmeter, karena tipe motor yang digunakan sebagai alat penggeraknya ialah motor listrik. Nilai untuk kebutuhan daya mesin terpampang langsung pada layar clampmeter. Motor listrik yang digunakan pada mesin ini ialah motor listrik 3 phase dengan merk TECO yang memiliki spesifikasi yaitu daya mesin sebesar 1,5 HP dan kecepatan putar ratarata sebesar 1490 rpm. Kebutuhan daya mesin menghasilkan nilai rata-rata sebesar $0,19 \mathrm{~kW}$ untuk pengukuran tanpa beban dan nilai rata-rata sebesar 0,22 kW untuk pengukuran dengan beban. Dari hasil tersebut maka dapat diketahui bahwa kebutuhan daya mesin akan meningkat apabila mesin mengolah bahan.

\section{Energi Spesifik Mesin}

Energi spesifik mesin pemecah kemiri sunan MPC KS0218 merupakan besarnya nilai energi yang diperlukan untuk memecahkan cangkang pada setiap $1 \mathrm{~kg}$ biji kemiri sunan. Nilai energi spesifik sebesar 17,08 kJ/kg. Energi spesifik akan semakin besar apabila kapasitas aktual mesin semakin kecil, akan tetapi nilai energi spesifik akan semakin kecil apabila kebutuhan daya semakin besar.

\section{Putaran Poros Mesin}

Putaran poros mesin pemecah cangkang kemiri sunan MPC KS-0218 diukur pada tiga tempat berbeda yaitu puli motor penggerak, puli rol pemecah, dan puli ayakan getar dan dilakukan pada dua kondisi yaitu tanpa beban dan dengan beban. Putaran poros rol pemecah menunjukkan hasil yang sama dengan putaran motor penggerak, yaitu akan melambat ataupun bertambah cepat sesuai dengan massa bahan yang diproses meskipun sampel bahan dari setiap ulangan sama-sama $5 \mathrm{~kg}$. Nilai pada layar tachometer akan sedikit berubah apabila tangan penguji bergerak sedikit saja.

Hasil pengukuran putaran motor penggerak memiliki nilai rata-rata sebesar $1488 \mathrm{rpm}$ untuk keadaan tanpa beban, serta memiliki nilai rata-rata sebesar 1489 rpm untuk keadaan dengan beban (Gambar 6) , hasil pengukuran putaran poros mesin (menuju rol pemecah) memiliki nilai rata-rata sebesar $1108 \mathrm{rpm}$, serta memiliki nilai rata-rata sebesar 1104 rpm untuk pengukuran dengan beban, sedangkan hasil pengukuran putaran poros mesin (menuju ayakan getar) dengan nilai rata-rata sebesar 796 rpm untuk keadaan tanpa beban, serta nilai rata-rata sebesar $793 \mathrm{rpm}$ untuk keadaan dengan beban. Hasil pengukuran rpm menunjukkan bahwa ada atau tidaknya bahan yang diolah, kecepatan putar pada puli masingmasing bagian tidak memiliki perubahan yang signifikan.

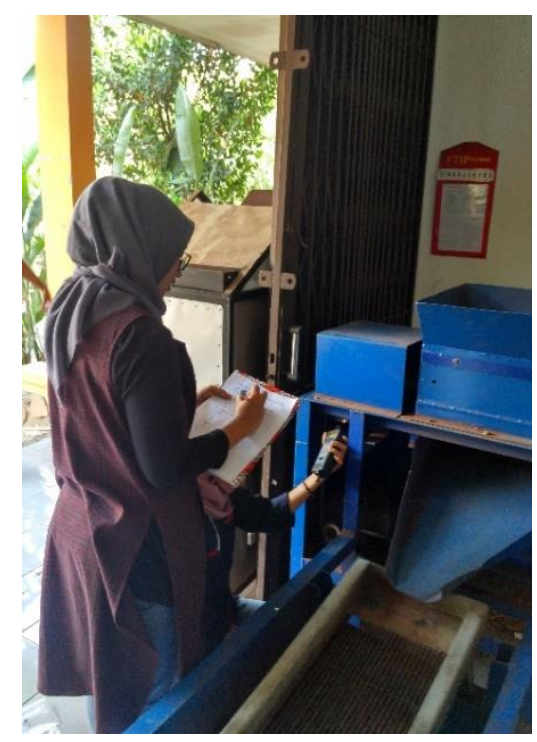

Gambar 6. Pengukuran putaran poros mesin

\section{Rendemen Pemecahan}

Rendemen pemecahan cangkang kemiri sunan menggunakan mesin MPC KS-0218 merupakan perbandingan antara massa kemiri sunan bagian inti utuh dan terpecah utuh dengan total massa kemiri sunan yang dimasukkan pada ruang pemecah tiap satu kali pengujian. Nilai rendemen pemecahan terhadap kemiri terpecah cangkang sebesar $39,48 \%$. Nilai rendemen yang dihasilkan dari proses pemecahan tersebut menunjukkan pada kenyataannya output per input tidak mungkin mendekati $100 \%$. Nisbah kemiri sunan adalah perbandingan pada 1 biji kemiri sunan yang terbagi atas cangkang dan inti, nilai nisbah kemiri sunan adalah sebesar $47,20 \%$ sedangkan inti sebesar 52,80 \% (Gambar 7). Hasil tersebut menunjukkan bahwa rendemen yang paling baik adalah 
$52,80 \%$ untuk keluaran berupa inti kemiri sunan (utuh maupun terbelah), sedangkan hasil yang diperoleh sebesar $39,48 \%$. Data menunjukkan bahwa rendemen yang didapatkan pada proses pemecahan cangkang kemiri sunan sudah layak.

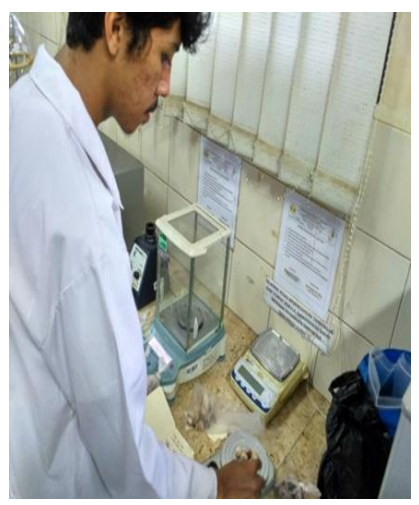

Gambar 7. Pengukuran nisbah kemiri sunan

\section{Tingkat Kebisingan Mesin}

Tingkat kebisingan mesin pemecah cangkang kemiri sunan MPC KS-0218 memiliki sumber kebisingan dari beberapa lokasi, diantaranya adalah ruang pemecahan, unit ayakan, dan motor listrik. Pengukuran tingkat kebisingan mesin menggunakan alat soundlevel meter.

Tingkat kebisingan mesin untuk kondisi tanpa beban rata-rata sebesar $78,62 \mathrm{~dB}$ serta untuk kondisi dengan beban sebesar $82,72 \mathrm{~dB}$. Tingkat kebisingan mesin masih dalam ambang wajar karena pada OSHA 1910.95 (Occupational Safety and Health Administration) tertera bahwa batas kebisingan untuk 4 jam kerja/hari adalah sebesar $95 \mathrm{~dB}$ dan untuk 6 jam kerja/hari sebesar $92 \mathrm{~dB}$. Nilai ambang batas kebisingan menurut Keputusan Menteri Tenaga Kerja (KEPMENAKER) No. Kep 51/MEN/1999, bahwa untuk 4 jam kerja/hari adalah sebesar $88 \mathrm{~dB}$ dan untuk 8 jam kerja/hari adalah sebesar $85 \mathrm{~dB}$. Oleh karena itu tingkat kebisingan mesin masih baik untuk digunakan selama 4 jam kerja/hari, 6 jam kerja/hari ataupun 8 jam kerja/hari. Dasar acuan mengenai tingkat kebisingan dari OSHA maupun KEPMENAKER sama-sama dapat diaplikasikan untuk keamanan kerja.

\section{Tingkat Getaran Mesin}

Hasil pengukuran tingkat getaran mesin memiliki nilai getaran sebagai berikut, pada hopper ketika tanpa beban (beban kosong) dengan nilai rata - rata adalah $7,5 \mathrm{~m} / \mathrm{s}^{2}$. Sedangkan untuk getaran pada hopper ketika dengan beban (beban isi) dengan nilai rata - rata $11,4 \mathrm{~m} / \mathrm{s}^{2}$. Hopper merupakan bagian paling penting pada analisis tingkat getaran mesin, hal ini karena langsung mengenai lengan dan tangan operator.

Nilai ambang batas getaran pada lengan dan tangan menurut Menteri Tenaga Kerja dan Transmigrasi Republik Indonesia No. PER.13/X/2011 pada waktu kerja/hari selama 4 jam dan kurang dari 8 jam yaitu sebesar $4 \mathrm{~m} / \mathrm{s}^{2}$. Ditinjau dari hasil pengukuran getaran mesin pemecah kemiri pada bagian hopper yang digunakan tidak memenuhi syarat karena mesin menghasilkan getaran rata-rata sebesar 7,43 m/s $/ \mathrm{s}^{2}$ ketika tanpa beban dan 10,85 m/s $/ \mathrm{s}^{2}$ ketika ada beban (beban isi), sedangkan ambang batasnya hanya $4 \mathrm{~m} / \mathrm{s}^{2}$.

\section{Tingkat Kebersihan Pemecahan}

Tingkat kebersihan pemecahan cangkang kemiri sunan MPC KS-0218 bertujuan untuk mengetahui persentase massa inti utuh dan terpecah dibandingkan dengan massa total melalui saluran keluaran pada setiap ulangan pengujian. Massa bahan yang keluar dari saluran keluaran ditimbang lalu diklasifikasikan menjadi beberapa bagian. Bagian dari biji kemiri sunan tersebut adalah inti utuh, inti terbelah, inti menempel cangkang, cangkang, kotoran, serta biji utuh. Tingkat kesesuaian pemecahan terbagi kedalam 2 saluran keluaran yaitu saluran primer dan saluran sekunder.

Hasil pengukuran menunjukkan tingkat kesesuaian saluran 1 dinilai dari perbandingan antara inti utuh dengan cangkang, sedangkan kesesuaian saluran 2 dinilai dari perbandingan antara inti terbelah dan cangkang. Pada saluran 1 tidak terdapat banyak cangkang yang ikut masuk, akan tetapi untuk saluran 2 masih banyak tercampur cangkang. Saluran 3 merupakan tempat keluarnya cangkang dan kotoran sehingga tidak perlu dihitung tingkat kesesuaian pemecahannya. Berdasarkan tabel rekapitulasi hasil uji kinerja, mesin memiliki tingkat kesesuaian pemecahan saluran keluaran primer rata-rata sebesar $67,087 \%$ (Gambar 8) menunjukkan bahwa inti utuh yang keluar dari saluran ini sudah sesuai.

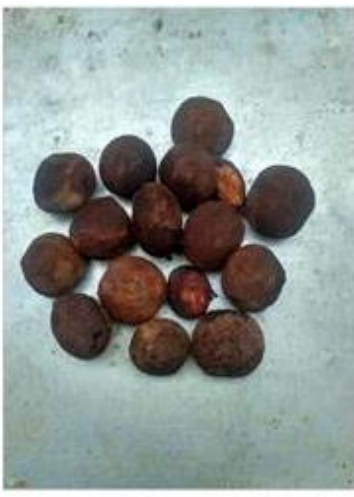

Biji Kemiri Sunan Biji Utuh

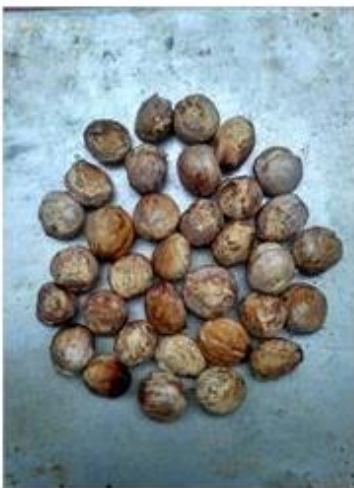

Biji Kemiri Sunan Inti Utuh

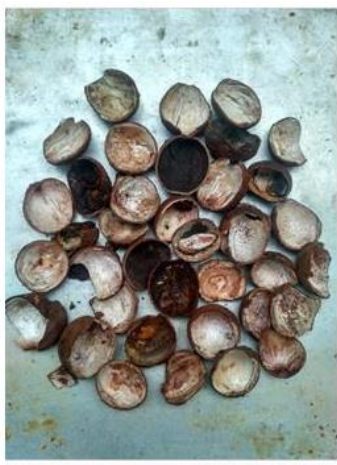

Biji Cangkang Kemiri Sunan

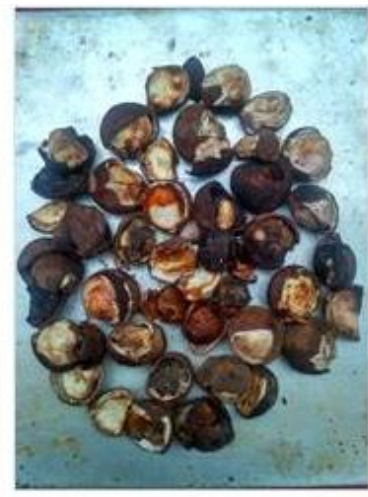

Biji Kemiri Sunan Inti

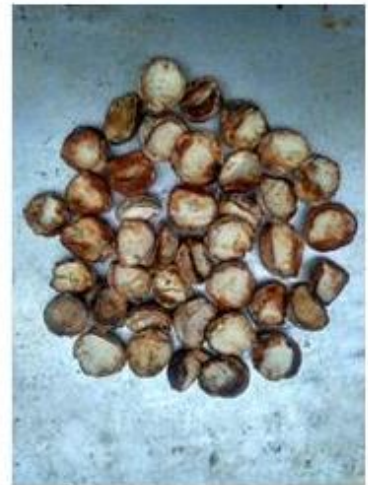

Biji Kemiri Sunan Inti Terpecah

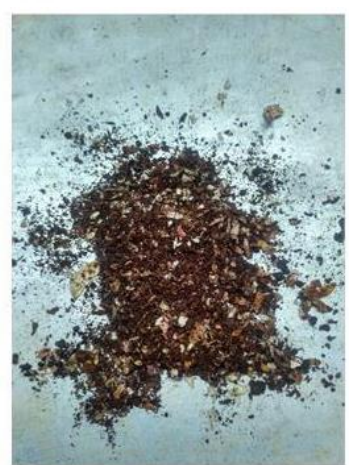

Kotoran Pemecahan Kemiri Sunan
Gambar 8.Tingkat kebersihan kemiri sunan 


\section{Efisiensi Mesin}

Indeks performansi adalah nilai yang menunjukkan fungsi suatu kerja mesin. Besarnya nilai indeks performansi mesin berkisar 0-1 dan yang terbaik adalah mendekati nilai 1 (Herwanto dkk. 1999). Hasil perhitungan indeks performansi pemecahan sebesar 0,72. Indeks performansi mesin masih belum memenuhi kriteria karena nilai rataratanya jauh dari angka 1 yang disebabkan masih banyaknya inti kemiri sunan yang tersangkut pada ayakan getar, sehingga inti kemiri yang terpecah utuh tidak dapat keluar semua menuju bagian output. Untuk fungsi pemecahan kemiri sudah memenuhi kriteria karena banyak cangkang yang terpecah, akan tetapi ayakan masih memiliki kekurangan yaitu jarak antar lubang yang terlalu dekat $\pm 2 \mathrm{~cm}$ sehingga banyak inti terbelah yang tersangkut, sehingga menyebabkan performa mesin secara keseluruhan terhambat.

\section{Rekapitulasi Data Hasil Uji Kinerja}

Adapun data hasil uji kinerja seperti disajikan pada Tabel 1.

Tabel 1. Rekapitulasi Data Hasil Uji Kinerja

\begin{tabular}{|c|c|c|c|c|c|}
\hline No & Uraian & Satuan & Rata-rata & Standar & Keterangan \\
\hline 1 & Kapasitas Aktual & $\mathrm{kg} / \mathrm{jam}$ & 49 & 60 (kriteria perancangan) & Tidak Memenuhi \\
\hline 2 & Efisiensi & $\%$ & 42 & Standar $>80$ & Tidak Memenuhi \\
\hline 3 & Indeks Performansi & - & 0,70 & 1 & Tidak Memenuhi \\
\hline 4 & Kebutuhan Daya & $\mathrm{kW}$ & $\begin{array}{c}\text { Tanpa beban }=0,19 \\
\text { Dengan beban }=0,22\end{array}$ & - & Memenuhi \\
\hline 5 & Energi Spesifik & $\mathrm{kJ} / \mathrm{kg}$ & 17,08 & - & Memenuhi \\
\hline 6 & Kebisingan & $d B$ & $\begin{array}{c}\text { Tanpa beban }=78,62 \\
\text { Dengan beban }=82,72\end{array}$ & 88 & Memenuhi \\
\hline 7 & $\begin{array}{l}\text { Kecepatan Putar } \\
\text { Poros Motor }\end{array}$ & rpm & $\begin{array}{l}\text { Tanpa beban }=1488 \\
\text { Dengan beban }=1489\end{array}$ & - & Memenuhi \\
\hline 8 & Tingkat Getaran & $\mathrm{m} / \mathrm{s}^{2}$ & $\begin{aligned} \text { Tanpa beban } & =8,94 \\
\text { Dengan beban } & =13,41\end{aligned}$ & 4 & Tidak Memenuhi \\
\hline 9 & Rendemen & $\%$ & 39,48 & 52,80 (nisbah) & Memenuhi \\
\hline
\end{tabular}

\section{Analisis Ekonomi}

Analisis ekonomi terhadap mesin pemecah cangkang kemiri sunan MPC KS-0218 merupakan suatu metode perhitungan yang digunakan untuk mengetahui nilai ekonomis dari mesin tersebut. Selain itu analisis ekonomi dihitung untuk mengetahui keuntungan dan kerugian dari suatu usaha dengan menggunakan mesin tersebut. Metode analisis ekonomi dilakukan dengan menghitung biaya pokok, break event point (BEP) atau titik impas usaha, serta analisis kelayakan ekonomi. Analisis kelayakan ekonomi terdiri dari nilai NPV (Net Present Value), PBP (Pay-back Period), IRR (Internal Rate of Return) serta B/C Ratio (Benefit Cost Ratio).

\section{Biaya Pokok dan BEP}

Biaya pokok pada perhitungan ini adalah sebagai berikut; Biaya pengoperasian mesin pemecah cangkang kemiri MPC KS-0218 per tahunnya ialah sebesar Rp. 164.261.096,00. Yang terdiri dari biaya tetap dan biaya biaya tidak tetap. Pemasukan kotor mesin tersebut ialah sebesar Rp. 183.456.000,00 untuk setiap tahunnya. Nilai hasil perhitungan biaya pengoperasian mesin dan pemasukan kotor mesin digunakan untuk menghitung break event point (BEP) atau titik impas usaha, serta analisis kelayakan ekonomi.

Titik impas usaha berdasarkan hasil perhitungan yang telah dilakukan akan dicapai ketika mesin telah memproses $\pm 8.562 \mathrm{~kg}$ biji kemiri sunan (Gambar 9). Hasil perhitungan diperoleh berdasarkan besarnya pemecahan biji kemiri sunan dalam kurun waktu satu tahun. Total biaya tetap dibagi (harga kemiri kupas - biaya variabel $/ \mathrm{kg}$ ).

\section{Analisis Kelayakan Ekonomi}

Berdasarkan hasil analisis ekonomi menunjukkan bahwa mesin belum memenuhi kriteria kelayakan ekonomi. Nilai kelayakan ekonomi yang didapatkan adalah sebagai berikut, Nilai NPV telah memenuhi syarat karena memiliki nilai Rp. 85.351.366,37 dimana kriteria terpenuhi apabila NPV > 0, nilai IRR telah terpenuhi karena bernilai 51,98\% dimana kriteria terpenuhi apabila nilai IRR > MARR (10\%) serta nilai $B / C$ ratio senilai 1,08 dimana $B / C$ Ratio akan tercapai apabila nilainya $>1$. Parameter kelayakan ekonomi terdiri dari 4 aspek yaitu Net Present Value (NPV), Internal Rate of Return (IRR), Benefit Cost Ratio (B/C Ratio) dan Pay-back Period (PBP) dan semuanya memenuhi kriteria terkecuali nilai $B / C$ Ratio karena hanya memiliki nilai sebesar 1,08 dengan nilai yang baik sebesar 1,1 - 1,4. Oleh karena itu mesin belum layak untuk dipabrikasi dan diperjualbelikan.

\section{Rekapitulasi Hasil Analisis Ekonomi Mesin MPC KS- 0218}

Hasil analisis ekonomi mesin MPC KS-0218 secara detail tersaji pada Tabel 2.

Tabel 2. Rekapitulasi Data Analisis Ekonomi Mesin MPC KS-0218

\begin{tabular}{clcc}
\hline No & Data & Jumlah & Keterangan \\
\hline 1 & BEP & $8.562 \mathrm{~kg}$ & - \\
2 & NPV & Rp. 85.351.366,37 & Memenuhi $>0$ \\
3 & IRR & $51,98 \%$ & Memenuhi $>10 \%$ \\
4 & B/C Ratio & 1,08 & Memenuhi $>1$ \\
5 & PBP & 1,77 Tahun & - \\
\hline
\end{tabular}




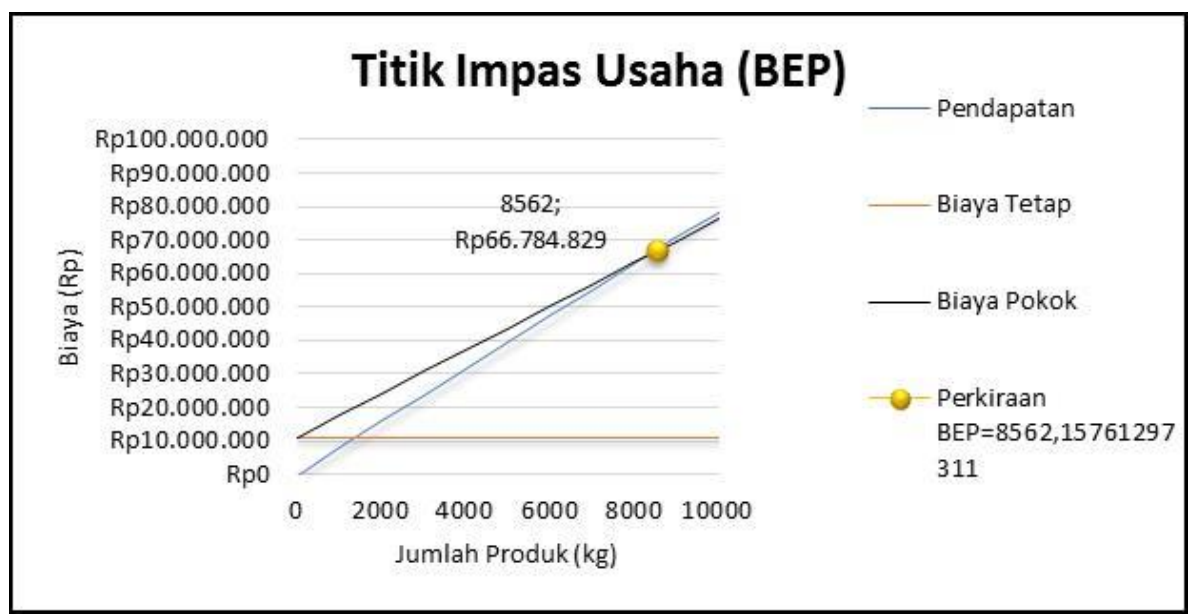

Gambar 9. Kurva titik impas kemiri sunan

\section{KESIMPULAN}

Kesimpulan dari penelitian mengenai uji kinerja mesin pemecah cangkang kemiri sunan (MPC KS-0218) adalah hasil pengujian kinerja mesin pemecah cangkang kemiri sunan MPC KS-0218 yang telah dilakukan menunjukkan belum memenuhi kriteria yang telah ditetapkan secara teknis; kapasitas aktual sebesar $49 \mathrm{~kg} / \mathrm{jam}$; efisiensi mesin sebesar 42\%; indeks performansi mesin sebesar 0,72; kebutuhan daya mesin dengan beban sebesar 0,22 kW; energi spesifik mesin sebesar $17,08 \mathrm{~kJ} / \mathrm{kg}$; rendemen pemecahan sebesar 39,5\% dengan nisbah inti kemiri sebesar $53 \%$; kecepatan putar poros motor (RPM) dengan beban sebesar 1489 RPM; tingkat kebisingan mesin sebesar 87,72 db ketika mengolah bahan; dan tingkat getaran mesin dengan beban sebesar $13,41 \mathrm{~m} / \mathrm{s}^{2}$.

Sedangkan hasil analisis ekonomi adalah BEP tercapai apabila telah memproses bahan sebanyak $8.562 \mathrm{~kg}$ dengan nilai PBP dicapai pada tahun kedua; NPV adalah Rp. 85.351.366,37; IRR adalah $51,98 \%$ dan b/c ratio memiliki nilai sebesar 1,08 .

\section{DAFTAR PUSTAKA}

Badan Standarisasi Nasional, 2013. SNI 7805:2013. Mesin Pemecah Biji dan Pemisah Kulit Kakao - Syarat Mutu dan Metode Uji. Jakarta: Badan Standarisasi Nasional.

Blank, L. \& A. Tarquin. 2002. Engineering Economy. McGraw-HillCompanies, Inc. United State of America.

Grant EL, Dkk. 1996. Dasar-dasar Ekonomi Teknik. PT Rineka Cipta. Jakarta.

Herman, M., dkk. 2013. Kemiri Sunan (Reutalis trisperma (blanco) Airy Shaw) Tanaman Penghasil Minyak Nabati dan Konservasi Lahan. IAARD Press. Jakarta.

Herman, M. dan D. Pranowo. 2009. Karakteristik Buah dan Minyak Kemiri Sunan (Reutalis trisperma (Blanco) Airy Shaw) populasi Majalengka dan Garut. Buletin Ristri 2(1):21-27.

Heyne, K. 1987. Tumbuhan Berguna Indonesia. Terjemahan: Badan Litbang. Kehutanan Jakarta. Jilid II dan III. Cetakan kesatu. Jakarta:Yayasan Sarana

Herwanto, T., R. Dadi dan T. Pujianto. 1999. Penilaian Performance Indeks Komponen Rice Milling Unit (RMU). Laporan Penelitian Jurusan Teknologi Pertanian. Fakultas Pertanian.

Kastaman, R. 2004. Ekonomi Teknik untuk Pengembangan Kewirausahaan. Bandung: Pustaka Giratuna dan ELOC-Universitas Padjadjaran.
Kiyaku Yaswaki dan Murdana DM, Teknik Praktis Merawat Sepeda Motor, Bandung: CV Pustaka. Grafika, 1998 Kuncoro, Mudrajad. 2003. Metode Riset untuk Bisnis dan Ekonomi. Jakarta : Erlangga

RNAM (Regional Network Agriculture Machiner) Test Codes and Procedures for Farm Machinery. 1995. UNINDO, United States of America.

SNI (Standar Nasional Indonesia) 4511. 2011. Syarat Mutu dan Cara Uji Mesin Penggiling Padi Sekali Umpan Tipe Rol Karet.

Saravacos, G. \& Kostaropaulos, A., 2002. Handbook of Food Processing Equipment. New York: Kluwer Academic/Plenum Publisher.

Sularso, Kiyokatsu Suga. 2004. Elemen Mesin. Jakarta: Pradnya Paramita.

Thuesen, Gerald J., Fabrycky, W. J. 2002. Ekonomi Teknik, Jilid Satu. PT Prenhallindo. Jakarta.

Vossen, HAM dan B.E. Umali. 2002. Plant Resources of SouthEast Asia No 14. Prosea Foundation. Bogor, Indonesia. 